\title{
Indonesian Journal of
}

Teaching in Science

\section{Assessing the Impact of Academic Self-Efficacy on Academic Performance of University Science Students in Katsina State, Nigeria}

Suleiman A. Isah', Adekunle Thomas Olutola ${ }^{2}$ *, Rafiu Ademola Olatoye ${ }^{2}$, Adegoke Adediji Aderogba ${ }^{3}$

${ }^{1}$ Department of Science and Vocational Education, Umaru Musa Yar'adua University, Katsina State, Nigeria.

2 Department of Educational Foundations, Faculty of Education, Federal University Dutsin-Ma, Katsina State, Nigeria.

${ }^{3}$ Department of Science, Technology and Mathematics Education, College of Education, Osun State University, IpetuIjesa Campus, Osun State, Nigeria

*Correspondence: E-mail: olutolatola@gmail.com \& aolutola@fudutsinma.edu.ng

\begin{abstract}
A B S T R A C T S
This study assesses the impact of academic self-efficacy on the academic performance of university science students in Katsina State, Nigeria. One research question and three null hypotheses were formulated. A descriptive survey research design was adopted where 320 randomly selected students from mathematics, physics, chemistry, and biology departments in the four universities in the state were selected. Academic Self-Efficacy Scale and students CGPA record was used as data collection tools which were analyzed using frequency count, percentage, Pearson Product Moment Correlation, Linear Regression, and ANOVA. The result of the study revealed that the majority of the students have either moderate or high academic self-efficacy, but belong to either a third class and/or lower second class degrees. A weak significant positive correlation existed between students' academic self-efficacy and performance $(r=0.12 ; p<0.05)$. Self-efficacy significantly contributed $1.5 \%$ to the total variance of academic performance $(R 2=0.015$, $\mathrm{F} 1,292=4.03 ; \mathrm{p}<0.05)$. However, there is no significant difference in the academic performance of low, moderate, and high academic self-efficacious students $(F 2,292=2.318$, $p>0.05)$. The researchers recommend that school counselors should improve students' academic self-efficacy to enhance students' academic performance.
\end{abstract}

\author{
ARTICLE INFO \\ Article History: \\ Submitted/Received 30 Sep 2020 \\ First revised 04 Oct 2020 \\ Accepted 06 Oct 2020 \\ First available online 08 Oct 2020 \\ Publiation date 01 Sep 2021 \\ Keyword: \\ Academic Performance, \\ Academic Self-Efficacy, \\ Science Students, \\ University.
}




\section{INTRODUCTION}

The contemporary world has reached a significant degree of advancement as compared to the medieval period in terms of science and technology. The effectiveness of the modern transportation, communication, and health management system, as well as sustainable agricultural practices, which become part of the pride of the 21st century, is made possible from the realities of modern science and technology. Science education played a significant role in this regard, by popularizing and spreading the principles of science across the globe. According to Aina (2014), science education is fundamental to the science and technology of any nation in the world. The practicing and implementation of science and science products (technology) spread all over the world quickly by the teaching and learning of science and science courses in schools. Most programs run by tertiary educational institutions, especially in the universities provide the highest level of manpower training in science and technology.

University is the highest level of education where high-level manpower, intellectual, and future leaders are developed (Olutola \& Olatoye, 2015). Higher education is regarded as an instrument of social, political, and economic development. The products of higher education in any nation will determine the development of such a nation. Therefore, higher education contributes to national development through high-level relevant manpower training; to acquire both physical and intellectual skills which enable individuals to be self-reliant and useful members of the society. The Federal Republic of Nigeria, has underscored the importance of science, did not only devoted a greater proportion of expenditure on science in university education but also authorized universities to allocate not less than $60 \%$ of admission places to science courses in the conventional universities.

It is important to note that, despite this huge investment, science students' academic performance in universities has not been encouraging. Numerous students are admitted yearly, unfortunately, many have withdrawn before graduation due to poor academic performance. This is evident in a list of almost one thousand students withdrawn within four sessions (2014/15 - 2018/19 sessions) as published on the Umaru Musa Yar'adua University (UMYU) website. It is sad to note that, more than half of the withdrawn students are science students. In a study comparing students' performance across Colleges of Agricultural Sciences, Business and Social Sciences, as well as College of Science and Engineering in Landmark University, science and engineering students, had the worst performance. The problem seems to be a mismatch between students and their performance in the university. Concluded that there is no relationship between students' chemistry University Matriculation Examination (UME) scores and their performance in the chemistry-based course at the University of Nigeria Nsukka and Enugu State University of Technology. This means that high scores obtained by students in UME do not guarantee a higher cumulative grade point average in university.

Science students' academic performance continues to take the back banner. This has sparked different areas of research on factors impeding students' success in universities. Most researches conducted focused on instructional strategies and the learning environment. Little attention is given to the students' psychological readiness to learn. Students' psychological variables are the better determinant of students' performance. The argument is that the tendency of the university capacity to produce the desire net effect in manpower training will be dependent on the students' psychological readiness. That is, the quality of the university infrastructures and teaching is less effective on students' academic performance compared to the students' self-belief, feelings, and motivational orientation. 
Academic self-efficacy is one of the students' psychological variables that deal with students' self-belief, motivational orientation, and judgments about their ability to successfully attain educational goals (Baanu et al., 2016). Students' belief in their innate abilities involves valuing their cognitive strengths, determination, and perseverance to overcome obstacles that would interfere with utilizing their innate abilities to achieve academic goals. The strength of students' efficacy belief affects their choice for plans and actions (Hoy et al., 2006). Efficacious students do not only set goals and try hard to achieve the target goals (Meral et al., 2012) but they also exhibit coping behavior, and perseverance when they encounter difficulties, more organized and even perform better than students who doubt their learning capabilities.

Research interest on the correlation between self-efficacy and academic performance took the frontline after the work of Albert Bandura on social cognitive psychology. Bandura's Social Cognitive Theory clarifies how students tend to engage in learning based on their self-belief of competence and/or past success. In some empirical studies, a moderate positive correlation was found between self-efficacy and academic achievement (Honicke \& Broadbent, 2016; Ekeh \& Oladayo, 2015). Atoum \& Al-Momani (2018) and Meral, et al. (2012) revealed a high positive relationship between the variables. However, Baanu, et al., (2016) did not found a significant relationship between academic self-efficacy and students' performance. The controversy might be due to differences in students' interests. A student may be interested in Mathematics but not in the English Language. This difference in interest can trigger students to be more/less efficacious for some subjects. This study, therefore, assesses the university science students' academic efficacy concerning their academic performance.

The following research question was answered: What is the distribution of academic performance in relation to self-efficacy exhibited by university science students in Katsina State?

The following null hypotheses were tested at a 0.05 level of significance:

(i) $\mathbf{H O}_{1}$ : There is no significant relationship between academic self-efficacy and academic performance of University science students in Katsina State.

(ii) $\mathbf{H O}_{2}$ : There is no significant relative influence of self-efficacy on academic performance among university science students in Katsina State.

(iii) $\mathrm{HO}_{3}$ : There is no significant difference in the academic performance among the low, moderate, and high levels of self-efficacy of university science students in Katsina State.

\section{METHODS}

\subsection{Research Design}

This study adopted a descriptive survey research design. This research design was considered suitable for this study because the variables cannot be manipulated.

\subsection{Target Population and Sample}

The target population for the study comprised all the 300 level undergraduate science students in Universities in Katsina State, Nigeria. There are four universities in Katsina State; one federal (Federal University Dutsinma $(n=1167)$ ), one state (Umaru Musa Yar'adua University Katsina $(n=1,062)$ ) and two private-owned universities (Al-Qalam University Katsina $(n=1,045)$ and Cherish Enterprise Institute, Batsari $(n=242))$. That is, there are 3.516 years three science students in the four universities as of the 2018/2019 academic session. A purposive sampling technique was used to select four departments (mathematics, physics, chemistry, biology) from each university. These departments were purposively selected 
because they are evergreen in all the four universities in the State. From each of these departments, 20 students were randomly selected to participate in the study. A total of 320 students, therefore, formed the sample for the study.

\subsection{Instrumentation}

The academic Self-Efficacy Scale (ASES) adapted from Heyne et al. (1998) was used to collect data. ASES is 12 items, five-point scale calibrated and scored as follows; "Really sure I couldn't" = 1, "Probably couldn't" = 2, "Maybe" = 3, "Probably could" = 4, and "Really sure I could" $=5$. Examples of items on ASES include:

(i) When going to class for morning lectures, how sure are you of being able to cope with any inconvenience?

(ii) How sure are you that you could approach your lecturers about something?

(iii) How sure are you that you could do academic work set by lecturers?

The students' Cumulative Grade Point Average (CGPA) records were retrieved from the universities and used as a measure of the students' academic performance. Items on ASES were validated by experts in the Department of Education, Umaru Musa Yar'adua University Katsina, State, Nigeria. The Cronbach alpha reliability of ASES yielded 0.951.

\subsection{Method of Data Analysis}

The data collected were analyzed using Statistical Package for Social Sciences (SPSS) version 23. Research question one was answered using frequency count and percentage; Hypothesis one was tested using Pearson Product Moment Correlation, Hypothesis two was tested using linear regression while hypothesis three was tested using ANOVA. All the hypotheses were tested at a 0.05 level of significance.

\section{RESULTS}

\subsection{Research Question 1: What is the distribution of academic performance in relation to academic self-efficacy exhibited by university science students in Katsina State?}

In Table 1, out of 14 students exhibiting low academic self-efficacy, 4(28\%) are either in upper or lower second class while $5(35.7 \%)$ are in third class and $1(7.1 \%)$ are on probation. Out of 148 students exhibiting a moderate academic self-efficacy, 3(2.0\%) are in first class, $28(18.9 \%)$ are in upper second class, $57(38.5 \%)$ are in lower second class, 52(35.1\%) are in third class while $8(5.4 \%)$ are in probation. Out of 131 students exhibiting high academic selfefficacy, $4(3.1 \%)$ are in first class, $45(34.4 \%)$ are in upper second class, 36(27.5\%) are in lower second class, $42(32.1 \%)$ are in third class while $4(3.1 \%)$ are in probation. Conclusively, the majority of the students have either moderate or high academic self-efficacy; and as well fall under the third class or lower second class degree category. Figures 1, 2, and 3 show the visual display of the cross-tabulation and distribution of the students' academic self-efficacy and academic performance.

Table 1. Cross Tabulation of Academic Self-Efficacy and Cumulative Grade Point Average.

\begin{tabular}{lcccccc}
\hline \multicolumn{7}{c}{ Cumulative Grade Point Average } \\
\hline $\begin{array}{l}\text { Academic Self- } \\
\text { Efficacy }\end{array}$ & $\begin{array}{c}\text { First } \\
\text { Class }\end{array}$ & $\begin{array}{c}\text { Upper } \\
\text { Second Class }\end{array}$ & $\begin{array}{c}\text { Lower Second } \\
\text { Class }\end{array}$ & $\begin{array}{c}\text { Third } \\
\text { Class }\end{array}$ & Probation & Total \\
\hline Low & $0(0.0 \%)$ & $4(28.6 \%)$ & $4(28.6 \%)$ & $5(35.7 \%)$ & $1(7.1 \%)$ & $14(100.0 \%)$ \\
Moderate & $3(2.0 \%)$ & $28(18.9 \%)$ & $57(38.5 \%)$ & $52(35.1 \%)$ & $8(5.4 \%)$ & $148(100.0 \%$ \\
High & $4(3.1 \%)$ & $45(34.4 \%)$ & $36(27.5 \%)$ & $42(32.1 \%)$ & $4(3.1 \%)$ & $131(100.0 \%)$ \\
Total & $7(2.4 \%)$ & $77(26.3 \%)$ & $97(33.1 \%)$ & $99(33.8 \%)$ & $13(4.4 \%)$ & $293(100.0 \%)$ \\
\hline
\end{tabular}


Figure 1 provides a graphical display of the university science students' performance concerning their level of academic self-efficacy. There is the low performance of students with low academic self-efficacy. Not a single student who exhibited low academic self-efficacy had a first-class degree. The category of students who exhibited moderate academic self-efficacy had lower second class, third class, and probation than the category of students who exhibited high academic self-concept while the category of students who exhibited high academic self-efficacy had more first-class and upper second class than the category of students who exhibited moderate and low academic self-efficacy.

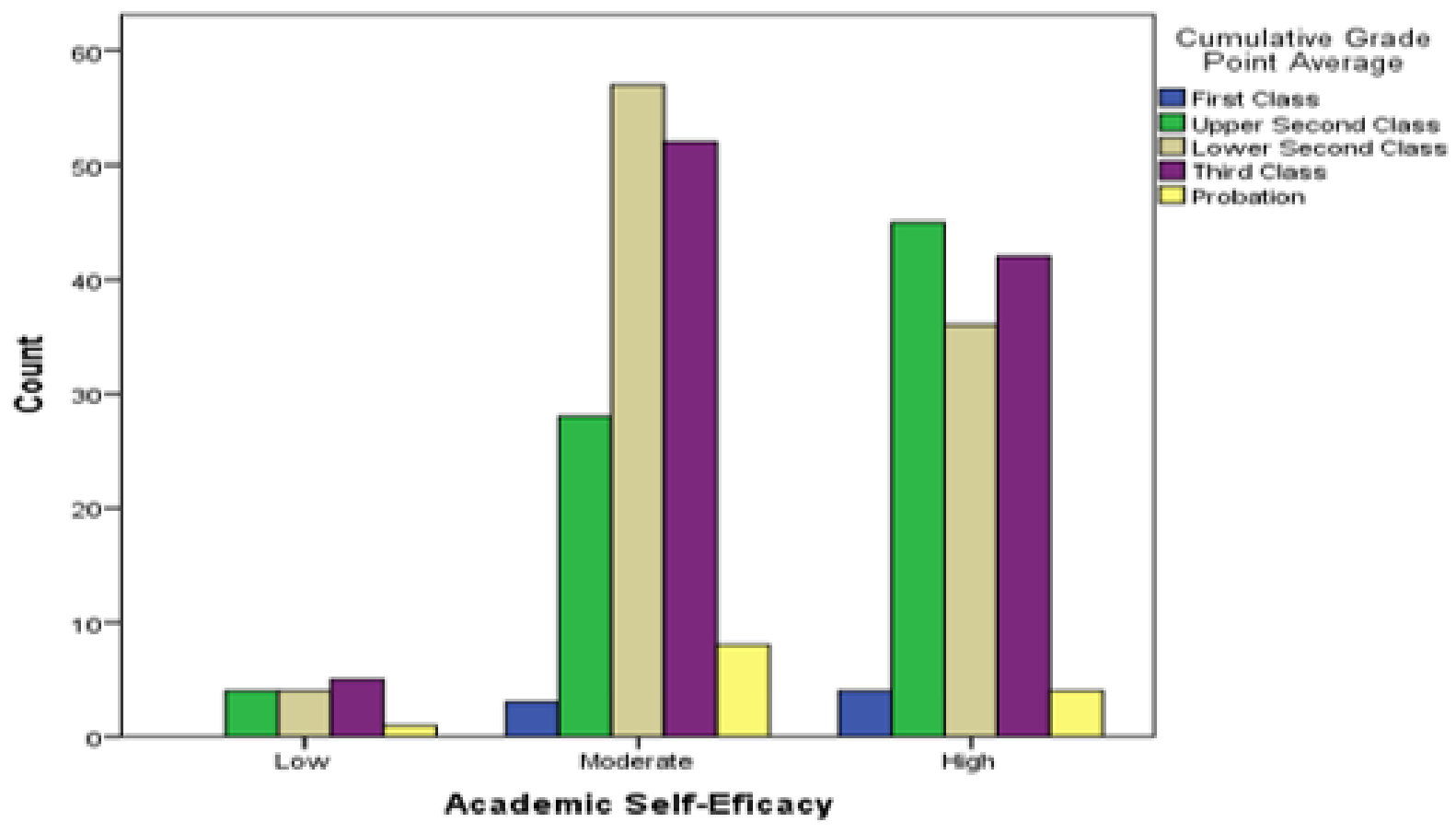

Figure 1. Visual display of students' academic self-efficacy level and academic performance.

Figure 2 shows the distribution of the students' academic performance as approximately normal. It means that there are fewer students whose performance is below or above average while the majority of the students' performance is at average.

Figure 3 showed that the distribution of the students' academic self-efficacy is approximately normal. This means that there are fewer students whose academic selfefficacy is below or above average while the majority of the students' academic self-efficacy is at average. 


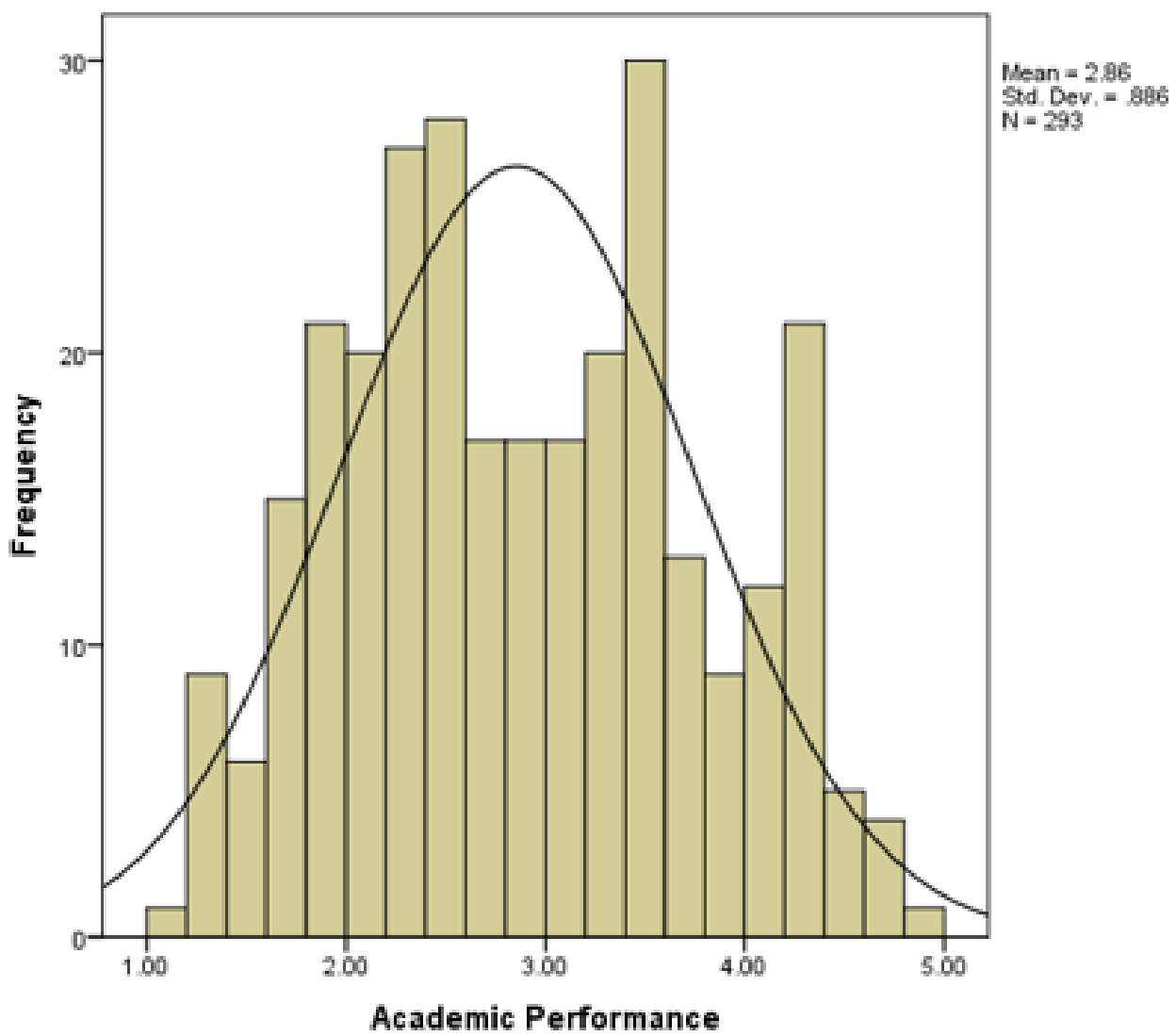

Figure 2. Normal Distribution of Students' Academic Performance.

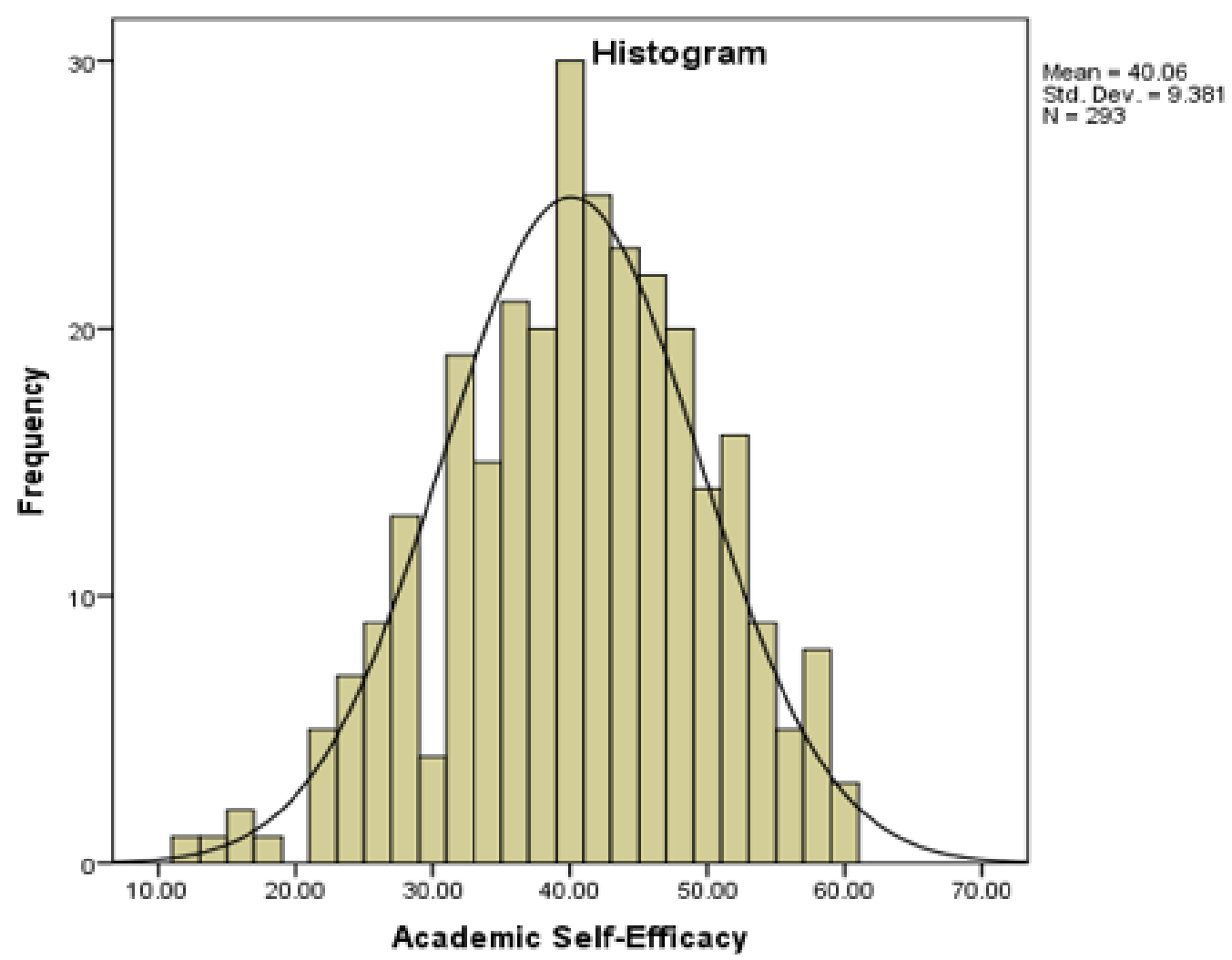

Figure 3. Normal Distribution of Students' Academic Self-Efficacy. 


\subsection{Hypothesis One: There is no significant relationship between academic self-efficacy and academic performance of University science students in Katsina State.}

In table 2, there is a weak but positive correlation between students' academic self-efficacy and academic performance. The relationship is however significant at 0.05 level $(r=0.12$; Sig $(2$-tailed $=0.39) ; p<0.05)$. This means that the relationship is linear. Thus, a unit increase in academic self-efficacy leads to a unit increase in academic performance.

Table 2. Relationship Between Students' Academic Self-Efficacy And Academic Performance.

\begin{tabular}{llcc}
\hline & & $\begin{array}{c}\text { Academic } \\
\text { Performance }\end{array}$ & $\begin{array}{c}\text { Academic } \\
\text { Self-Efficacy }\end{array}$ \\
\hline \multirow{2}{*}{ Academic Performance } & Pearson Correlation & 1 & $0.121^{*}$ \\
& Sig. (2-tailed) & & 0.039 \\
& $N$ & 293 & 293 \\
Academic Self-Efficacy & Pearson Correlation & $0.121^{*}$ & 1 \\
& Sig. (2-tailed) & 0.039 & \\
& $N$ & 293 & 293 \\
\hline
\end{tabular}

*. Correlation is significant at the 0.05 level (2-tailed).

3.3. Hypothesis Two: There is no significant relative influence of self-efficacy on academic performance among university science students in Katsina State.

In table 3, self-efficacy significantly contributed just $1.5 \%$ to the total variance in academic performance $(R 2=0.015, F 1,292=4.303 ; p<0.05)$. In another word, $1.5 \%$ of the variation in academic performance of the students can be explained by their academic self-efficacy. Other variables not captured in this study may be responsible for the remaining variance in the academic performance of the students. The null hypothesis in this regard is therefore rejected. This implies that there is a significant influence of academic self-efficacy on the academic performance of university science students in Katsina State.

Table 3. Regression Analysis Showing the Influence of Academic Self-Efficacy on Academic Performance of University Science Students in Katsina State.

$$
\mathbf{R}=\mathbf{0 . 1 2}
$$

R Square $=0.015$

Adjusted R Square $=0.011$

Std. Error of the Estimate $\mathbf{= 0 . 8 8 1 2 1}$

\begin{tabular}{lcccccc}
\hline \multicolumn{1}{c}{ Model } & $\begin{array}{c}\text { Sum of } \\
\text { Squares }\end{array}$ & df & $\begin{array}{c}\text { Mean } \\
\text { Square }\end{array}$ & F & Sig. & Remark \\
\hline Regression & 3.342 & 1 & 3.342 & 4.303 & 0.039 & $*$ Sig \\
Residual & 225.971 & 291 & 0.777 & & & \\
Total & 229.312 & 292 & & & & \\
\hline
\end{tabular}

*Significant at 0.05

3.4. Hypothesis Three: There is no significant difference in academic performance among the low, moderate, and high levels of self-efficacy of university science students in Katsina State.

Figure 4 provides a visual display of the mean plot of academic performance of the students with low, moderate, and high academic self-efficacy. It shows that the students performed at a different level based on their level of self-efficacy. However, the result in table 4 revealed that there is no significant difference in the academic performance of the students 
who exhibited low, moderate, and high academic self-efficacy $(F 2,292=2.318, p>0.05)$. In another word, the students' performance did not differ significantly irrespective of their academic self-efficacy. The null hypothesis in this regard is therefore retained.

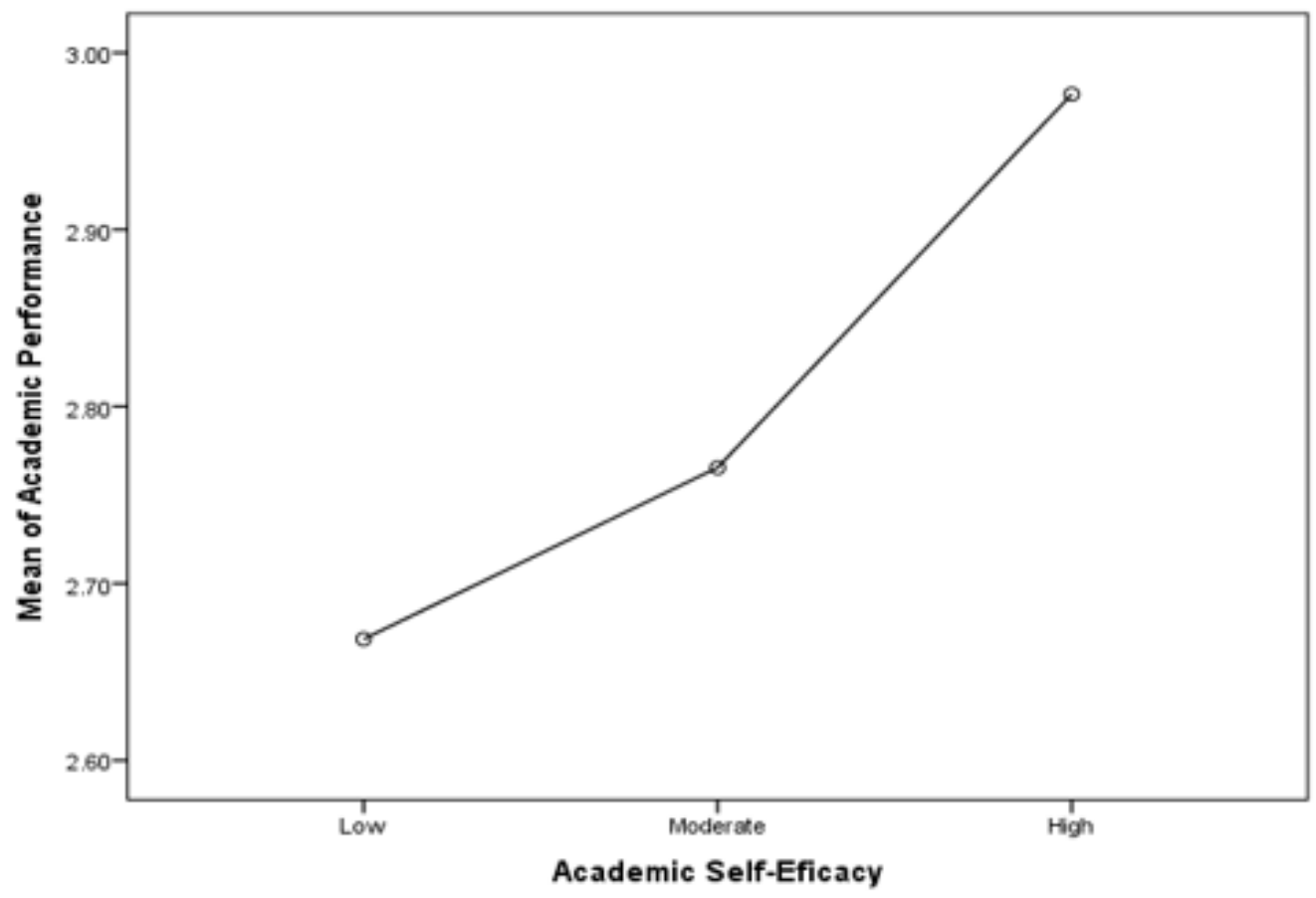

Figure 4. Mean plot of academic performance of low, moderate and high academic selfefficacy.

Table 4. ANOVA Analysis Showing Difference in the Academic Performance Among Low, Moderate and High Level of Self-Efficacy.

\begin{tabular}{lcccccc}
\hline & Sum of Squares & df & Mean Square & F & Sig. & Remark \\
\hline Between Groups & 3.609 & 2 & 1.804 & 2.318 & 0.100 & ${ }^{*}$ NS \\
Within Groups & 225.704 & 290 & 0.778 & & & \\
Total & 229.312 & 292 & & & & \\
\hline
\end{tabular}

* Not Significant at 0.05 level

\section{DISCUSSION OF FINDINGS}

This study revealed that the majority of the students exhibited either moderate or high academic self-efficacy and as well fall under the third class or lower second class degree category. But a good number of the students also belong to the upper second class. The students on probation outnumbered the students with a first-class degree. This finding is similar to the finding of Ali (2013) who found out that, students with Cumulative Grade Point Average in Kogi State University and College of Education Ankpa were at the second class lower division. However, Osaikhiuwu (2014) revealed that 53\% of Public Administration Students in Obafemi Awolowo University performed above average.

The study further revealed that the students' academic self-efficacy has a very low but significant positive relationship with academic performance. In another word, a linear relationship exists between the two variables; a unit increase in academic self-efficacy leads to a unit increase in academic performance. This finding agrees with the finding of Ekeh \& Oladayo (2015) who revealed a positive moderate relationship between academic self- 
efficacy and academic achievement. In a systematic review involving fifty-nine studies, Honicke \& Broadbent (2016) also revealed a moderate positive relationship and academic performance among university students. Findings of the study conducted by Atoum \& AlMomani (2018) which revealed a high positive relationship between self-efficacy and academic achievement also supported the results of hypothesis one.

The study also revealed that academic self-efficacy significantly contributed $1.5 \%$ to the total variance of academic performance. This means that academic self-efficacy is a good predictor of academic performance of University science students in Katsina State. This finding corroborates with the finding of Ekeh \& Oladayo (2015) that, self-efficacy and optimism jointly predicted academic performance among special need learners in Port Harcourt, Nigeria. In a study involving 480 students stated that academic self-efficacy significantly predicts students' achievement by $4.6 \%$. These findings, therefore, supported hypothesis two.

Another finding of this study is that the academic performance of low, moderate, and high self-efficacious students did not differ significantly. Atoum \& Al-Momani (2018), stated that students' academic achievement depends on the level of perceived self-efficacy in the sense that, the higher the self-efficacy, the higher the academic performance. The distribution of the students' academic self-efficacy and academic performance are approximately normally distributed across the population (see Figures 2 \& 3). The majority of the students' academic self-efficacy and performance fall in the middle. This normal distribution may account for the reason why there was no significant difference in the performance among the three levels of self-efficacy of the students.

Since academic self-efficacy is a good predictor of academic performance as uncovered in this study, it is hereby recommended that:

(i) Lecturers and school counselors should strategize ways to improve students' academic self-efficacy to enhance students' academic performance in schools.

(ii) Students should be regularly oriented about the effect of negative self-belief on their academic performance in school.

(iii) Students should be given admission into universities based on the course they feel they can perform and excel.

\section{CONCLUSION}

The study provides empirical information about the impact of academic self-efficacy on the academic performance of university science students in Katsina State, Nigeria. Academic selfefficacy relates linearly with academic performance and also contributed just little percentage to the variation in the students' academic performance despite the majority of the students have moderate or high academic self-efficacy. This calls for further research on other variables responsible for the remaining variance in the academic performance of the students.

\section{AUTHORS' NOTE}

The authors declare that there is no conflict of interest regarding the publication of this article. Authors confirmed that the paper was free of plagiarism. 


\section{REFERENCES}

Aina, J. K. (2014). Fundamental of science education in a pluralistic technology. Asian Academic Research Journal of Social Sciences and Humanities, 1(23), 282-294.

Ali, H. O. (2013). Factors affecting students' academic performance in mathematical sciences department in tertiary institutions in Nigeria. US-China Education Review, 3(12), 905-913.

Atoum, A. Y. and Al-Momani, A. (2018). Perceived self-efficacy and academic achievement among Jordanian students. Trends in Technical \& Scientific Research, 3(1), 1-6.

Baanu, T. F., Oyelekan, O. S., and Olorundare, A. S. (2016). Self-efficacy and chemistry students' academic achievement in senior secondary schools in North-Central, Nigeria. The Malaysian Online Journal of Educational Science, 4(1), 43 - 52.

Ekeh, P. U., and Oladayo, O. T. (2015). Optimism and self-efficacy as predictors of academic achievement among special needs learners. International Journal of Academic Research and Reflection, 3(7), $35-42$.

Heyne, D., King, N., Tonge, B., Rollings, S., Pritchard, M., Young, D., and Myerson, N. (1998). The self-efficacy questionnaire for school situations: development and psychometric evaluation. Behaviour Change, 15(1), $31-40$.

Honicke, T. and Broadbent, J. (2016). The relationship of academic self-efficacy to university student academic performance: a systematic review. Educational Research Review, 17, 63-84.

Hoy, W. K., Tarter, C. J., and Hoy, A. W. (2006). Academic optimism of schools: a force for student achievement. American Educational Research Journal, 43(3), 425 - 446.

Meral, M., Colak, E., and Zereyak, E. (2012). The relationship between self-efficacy and academic performance. Procedia - Social and Behavioral Sciences, 46, 1143 - 1146.

Olutola, A. T. and Olatoye, O. O. (2015). Challenges of E-learning Technologies in Nigerian University Education. Journal of Educational and Social Research, 5(1), 301-305.

Osaikhiuwu, O. C. (2014). Institutional factors affecting the academic performance of public administration students in a Nigerian University. Public Administration Research, 3(2), $171-177$. 